Hispania, 2013, vol. LXXIII, nº. 244, mayo-agosto, págs. 409-438

ISSN: 0018-2141, e-ISSN: 1988-8368, doi: 10.3989/hispania.2013.012

\title{
Paisaje, memoria histórica e identidad nacional en los inicios de la política de conservación de la naturaleza en España: de Covadonga a San Juan de la Peña ${ }^{1}$
}

\author{
Jacobo García Álvarez \\ Universidad Carlos III de Madrid
}

RESUMEN: Este artículo indaga en el concepto de "paisaje nacional» y en la importancia de los valores simbólicos de carácter identitario en los inicios de la conservación de la naturaleza y del paisaje y en la declaración de algunos de los primeros espacios protegidos en España, deteniéndose, de manera particular, en uno de los casos más relevantes y emblemáticos en este sentido: la creación del Parque Nacional de la Montaña de Covadonga. El trabajo se articula en tres partes: en la primera se plantean algunas consideraciones teóricas y generales sobre el papel de los valores simbólicos y, en particular, identitarios en los inicios de la conservación de la naturaleza y del paisaje en España; en la segunda se examina el proceso de patrimonialización del paisaje de la Montaña de Covadonga como lugar de memoria e identidad nacional, culminado, en lo sustancial, por la declaración del Parque Nacional, en 1918; y en la tercera y última se estudian las disputas y polémicas identitarias vinculadas a la declaración de dicho Parque y, en relación con ellas, los argumentos que condujeron a la declaración del Sitio Nacional del Monte de San Juan de la Peña en 1920. El artículo aborda la creación de los primeros parques naturales en España como parte de las políticas de nacionalización inspiradas en las inquietudes regeneracionistas y en los esfuerzos de ciertas élites y clases dirigentes por institucionalizar nuevos espacios de identidad colectiva en torno al paisaje y la naturaleza (y, más particularmente, en torno a ciertos paisajes naturales impregnados de historia y considerados fundacionales para la historia de nación). En este sentido, las controversias ideológicas suscitadas respecto a tales espacios reflejan la pluralidad de concepciones nacionales existentes en la España de la épo-

1 Este trabajo se ha realizado dentro del Proyecto de Investigación CSO2008-03877, financiado por el Ministerio de Educación y el FEDER. 
ca, así como las dificultades por consensuar unos símbolos nacionales compartidos.

Palabras Clave: Paisajes nacionales; Conservación de la naturaleza; Parques Nacionales; España; Covadonga; San Juan de la Peña.

Landscape, historic memory and national identity in the beginnings of the policy nature conservation in Spain: from Covadonga to San Juan de la Peña

ABSTRACT: This article reflects on the concept of "national landscape" and on the importance of identity symbolic values in the beginning of landscape and nature conservation policy in Spain. The emblematic case of the Montaña de Covadonga (the first National Park created in Spain) is examined in more detail. The paper is divided into three main sections. The first one raises some theoretical and general considerations on the role of identity symbolic values within the first steps of nature conservation policies in Spain and other national contexts. Secondly, the cultural-historic processes and discourses which converted the Montaña de Covadonga landscape into a Spanish national symbol and into a site of memory, leading to its declaration as a National Park in 1918, are reviewed. The third section examines the ideological identity disputes and controversies concerning the creation of that National Park, some of which led to the declaration of the Sitio Nacional del Monte de San Juan de la Peña in 1920. The article approaches the creation of the first Spanish Natural Parks as a part of the nationalization policies inspired by the concerns of the "Regeneracionismo". More precisely, the beginning of natural conservation policy in Spain may be considered as part of the efforts carried out by certain intellectual and political leaders in order to institutionalize new spaces of collective identity grounded in landscape and nature (and, more particularly, in some natural landscapes endowed with a strong historic symbolic meaning as regards to the "birth of the nation"). According to the research conclusions, the ideological controversies raised around the first Spanish Natural Parks can be understood as a reflection of the plurality of competing national conceptions existing in Spain, as well as of the difficulties in reaching a consensus on the country's national symbols.

KEY WORDS: National Landscapes; Nature Conservation; National Parks; Spain; Covadonga; San Juan de la Peña.

\section{INTRODUCCIÓN}

\section{«Paisajes nacionales» y conservación de la naturaleza en España}

La importancia del concepto moderno de paisaje, así como de los valores simbólicos vinculados a dicho concepto, en los inicios de las políticas de pro- 
tección de la naturaleza en España ha sido estudiada y resaltada en los últimos dos decenios por especialistas de muy diversas disciplinas ${ }^{2}$. Al igual que ocurrió en otros países pioneros, tanto dentro como fuera de Europa, en la creación de espacios naturales protegidos, los primeros pasos de las políticas de protección de la naturaleza en España, impulsados, fundamentalmente, a partir de la Ley de 1916 sobre Parques Nacionales, incorporaron una concepción moderna del paisaje que reconoció en éste valores no sólo naturales, sino también culturales, y que atribuyó a la conservación de los paisajes significados múltiples, algunos de ellos intensamente simbólicos. El primer objetivo de este trabajo estriba precisamente en examinar cómo dichos valores y significados, que forman parte de variadas «raíces culturales de la conservación de la naturaleza y de los paisajes $»^{3}$, incluyeron de forma medular el ingrediente identitario, patriótico y nacionalista e influyeron tanto sobre los argumentos fundacionales de tales políticas como sobre los criterios que se utilizaron para seleccionar y declarar los primeros espacios merecedores de protección. Como tratará de mostrar la investigación que aquí se expone, la conservación de la naturaleza y del paisaje se consideró en aquel momento, tanto en España como en muchos otros estados europeos, una tarea de profunda significación patriótica, capaz de reportar a la ciudadanía y al país beneficios múltiples y variados (económicos, educativos, científicos, recreativos o espirituales, entre otros, aparte de los estrictamente ecológicos), así como de fortalecer, al mismo tiempo, la identidad territorial nacional y regional. A lo que cabe añadir que algunos de los paisajes que se protegen efectivamente o que se propone proteger se escogen, entre otros criterios, por ser expresivos, en más o menos medida, de ciertos hechos, períodos o valores que se consideraban esenciales de la historia o de las identidad nacionales.

Tales espacios responderían, pues, a lo que el geógrafo Donald Meinig denominara a finales del decenio de 1970 los «paisajes simbólicos» constitutivos de la «la iconografía de la nacionalidad» ${ }^{4}$. Conformarían, utilizando la conocida expresión francesa, lugares emblemáticos (haut lieux) o «lugares de memoria», en el sentido conferido a este concepto, desde los años 80 del siglo pasado, por Pierre Nora. O, como se ha dicho más recientemente, constituirían una suerte de «paisajes nacionales», entendiendo por tales «aquellos paisajes o conjunto de paisajes que en el imaginario colectivo representan e identi-

2 La literatura sobre los orígenes de las políticas de conservación de la naturaleza en España es extensa. Dentro de ella, cabe citar, a modo de ejemplo, los trabajos de SOLÉ y BRETÓN, 63 (Barcelona, 1986). GÓMEZ, 1992. FERNÁNDEZ y PRADAS, 1996. MATA, 2000. ORTEGA, 2000. MULERO, 2002; CASADO, 2010.

3 ORTEGA, 2000.

4 MEINIG, 1979. 
fican los valores nacionales, la esencia de la nación» ${ }^{5}$, paisajes a los que se atribuía, por parte de ciertos autores y grupos, «la cualidad de condensar, expresar y simbolizar las claves de la correspondiente identidad nacional» ${ }^{6}$.

Las interpretaciones románticas de la nación y, de manera más amplia, las concepciones nacionales de carácter orgánico-historicista, aunque no sólo éstas, han vinculado estrechamente la identidad nacional con el territorio, la naturaleza y el paisaje; han visto en el territorio una suerte de receptáculo del pasado en el presente; han reconocido en el paisaje, en general, una expresión (material y simbólica) de la historia de los grupos humanos; han dotado de significado identitario colectivo a determinados paisajes y lugares, convirtiéndolos en lugares de memoria y en símbolos de la historia y el carácter nacional; y han contribuido, de este modo, a su valoración y protección como bienes patrimoniales. Son ya numerosos los estudios que, desde el decenio de 1980, han intentado explorar las «topografías patrióticas» —utilizando la expresión de otro geógrafo, Stephen Daniels ${ }^{7}$ - de las que forman parte esos lugares y paisajes de valor identitario, y en las que suelen integrarse escenarios de batallas, asedios y otros episodios bélicos considerados claves en la historia nacional; lugares de nacimiento de héroes, santos o figuras históricas relevantes; santuarios y centros religiosos de especial importancia; territorios fundacionales o protagonistas en el proceso de conformación de los estados correspondientes (esto que algunos autores anglosajones han denominado core areas o national heartlands $)^{8}$; territorios históricos originarios hoy perdidos o en manos de otros pueblos; espacios naturales valorados como excepcionales; o simplemente familias y tipos de paisajes, no necesariamente excepcionales, que las élites intelectuales y políticas han interpretado como la cuna y la plasmación material de las señas distintivas de una cultura ${ }^{9}$.

Los nacionalismos han forjado unas veces, o manipulado interesadamente otras, una verdadera retahíla de paisajes nacionales, que en ciertos casos han sido institucionalizados mediante figuras políticas y legales específicas (bajo la forma de parques naturales, conjuntos históricos protegidos, etc.), y en otros no han cuajado en figuras institucionales, aunque sí en imágenes y arquetipos de amplia proyección social.

Los inicios de la conservación de la naturaleza y del paisaje, cuyos primeros hitos legales, a escala internacional, suelen situarse en la década 1870 en

5 NOGUÉ, 2005.

6 ORTEGA 73-74 (Oviedo, 2007): 138. Personalmente, he reflexionado sobre la aplicación de la idea de paisaje nacional, así como la de la noción de lugar de memoria, a determinados paisajes españoles en GARCÍA ÁLVAREZ, 51 (Madrid, 2009); 73-74 (Oviedo, 2007).

7 DANIELS, 1993.

8 Sobre el primero de estos conceptos, que en castellano ha sido traducido como «área nuclear», véase TAYLOR y FLINT, 2002: 163-166; sobre el segundo, STOREY, 2001: 76-89.

9 GARCÍA ÁLVAREZ, 51 (Madrid, 2009): 184-189. 
Inglaterra (con la protección del parque londinense de Hampstead Heath, declarada en 1871) y en los Estados Unidos de América (con la creación del Parque Nacional de Yellowstone, en 1872), no escapan en modo alguno a la consideración de este tipo de valores y significados, como han puesto de manifiesto trabajos comparativos como los de Kenneth Olwig o el citado Daniels ${ }^{10}$, así como el de François Walter, que ha examinado esta cuestión a escala europea ${ }^{11}$. La importancia de tales argumentos quedó ejemplarmente resumida, igualmente, en las palabras de Charles Beauquier, fundador y presidente de la Societé pour la Protection des Paysages de France entre 1901 y 1915 , y principal promotor de la Ley sobre sitios y monumentos naturales de 21 de abril de 1906 (considerada la primera ley francesa de protección de la naturaleza), al referirse a «l'étroite union du paysage et de la patrie»:

À côté des fastes de l'histoire, des victoires et des conquêtes, des héros de la guerre et de la paix, il y a les landes et les grèves, les forêts et les monts, où passe encore le souffle, où flotte encore le souvenir des générations effacées, où s'est formée l'âme de la nation ${ }^{12}$.

Los comienzos de las políticas de conservación de la naturaleza en España se enmarcan, asimismo, como ha mostrado recientemente Santos Casado, en el contexto de las preocupaciones regeneracionistas que recorren los decenios finales del XIX y los primeros del XX y que conectan de forma estrecha la redefinición de la identidad nacional con una nueva mirada hacia la naturaleza y el paisaje, objetos de un auténtico descubrimiento cultural ${ }^{13}$. Esa mirada regeneracionista, compartida por grupos profesionales e ideológicos muy dispares, concibe el paisaje no sólo como un sustrato o recurso material cuyo conocimiento científico puede aportar las claves para la regeneración económica del país, sino también como una suerte de compendio - auténtico e inocente - de la nación, capaz de proporcionar a ésta un símbolo físico, tangible, de identidad colectiva, así como de fundamentar su regeneración moral y espiritual. Desde esa nueva óptica, aproximarse a la naturaleza y el paisaje aparece, a la vez, como una vía para escapar de la vida excesivamente artificial y urbana asociada a la nueva sociedad industrial y como una potente vía de acceso a lo que Rafael Altamira llamaba, en 1921, refiriéndose a Giner, «la más profunda raíz de patriotismo que emana de la tierra en que formó un pueblo su alma y su historia» ${ }^{14}$. Una vía que socializa el disfrute de la naturaleza a la

10 OLWIG, 2002; DANIELS, 1993.

11 WALTER, 2004.

12 Cfr. ASTIE, 1912: 169. WALTER, 2004: 273.

13 CASADO, 2010: 11-23.

14 ALTAMIRA, 45 (Madrid, 1921): 220. 
vez que interpreta la sociedad en clave naturalista, y en la que convergen caminos o modalidades de aproximación diversos, a menudo interconectados, tales como el naturalismo científico, los movimientos de renovación pedagógica (encabezados por el institucionismo), la literatura noventaiochista, el excursionismo, el alpinismo, el higienismo, el naturismo o el conservacionismo ${ }^{15}$.

En este sentido, y como intentará ilustrar la presente investigación, la creación de los primeros parques naturales en España se inscribe en las políticas de nacionalización inspiradas en el contexto cultural del regeneracionismo y en los esfuerzos de ciertas élites y clases dirigentes por institucionalizar nuevos espacios de identidad colectiva en torno al paisaje y la naturaleza (y, más particularmente, en torno a ciertos paisajes naturales impregnados de historia y considerados fundacionales para la historia de nación).

La estimación del este tipo de valores simbólicos resulta especialmente evidente e importante en los primeros años de las políticas de conservación de la naturaleza, comenzando por la citada Ley creadora de los Parques Nacionales, promulgada el 7 de diciembre de 1916, durante el gobierno de Eduardo Dato, siendo Ministro de Fomento Rafael Gasset. Se trata, como es sabido, de un texto muy breve, de apenas tres artículos, cuya preparación arrancó casi dos años antes con la proposición presentada el 10 de febrero de 1915 por el senador Pedro Pidal. La ley se limita a crear la figura y a manifestar la voluntad del Ministerio de Fomento de aplicarla a:

aquellos sitios o parajes excepcionalmente pintorescos, forestales o agrestes, del territorio nacional, que el Estado consagra, declarándolos tales, con el exclusivo objeto de favorecer su acceso por vías de comunicación adecuadas, y de respetar y hacer que se respete la belleza natural de sus paisajes, la riqueza de su fauna y de su flora y las particularidades geológicas e hidrológicas que encierren, evitando de este modo con la mayor eficacia todo acto de destrucción, deterioro o desfiguración por la mano del hombre ${ }^{16}$.

Como analizaré con más detalle en los siguientes apartados del trabajo, más allá de la retórica eminentemente naturalista de esta disposición, los valores de tipo identitario, nacionalista e historicista resultarían determinantes para la declaración de dos de los tres únicos espacios naturales protegidos creados en los siguientes cuatro años (dejando al margen los cotos reales de

15 Las dimensiones patrióticas e identitarias atribuidas al paisaje y al conocimiento del mismo por algunos de estos movimientos y horizontes culturales han sido estudiadas ampliamente en los últimos veinte años. A título de ejemplo, véanse los trabajos VARELA, 1993. FOX, 1997. MARTÍNEZ DE PISÓN, 1998. NÚÑEZ, 2004. ORTEGA, 73-74 (Oviedo, 2007); y MORALES MOLLA, 2008.

16 Art.2. de la Ley creadora de los Parques Nacionales en España (Gaceta de Madrid de 8 de diciembre de 1916: 575). 
caza declarados con anterioridad a la citada Ley), como fueron el Parque Nacional de la Montaña de Covadonga, aprobado en agosto de 1918, y el Sitio Nacional de San Juan de la Peña, establecido por Real Orden del 30 de octubre de 1920. Pero además, la consideración de esos valores, recogida en el Real Decreto de 23 de febrero de 1917, que desarrolló, a modo de Reglamento, el brevísimo contenido de Ley de 1916, tampoco fue ajena del todo a la declaración del segundo Parque Nacional creado en España, el del Valle de Ordesa, creado en agosto de 1918, y pesó de forma importante en la primera lista «oficial» de los espacios susceptibles de ser protegidos en España, elaborada en cumplimiento del citado Real Decreto: la relación de «Sitios Notables» inventariada por la Dirección General de Agricultura, Minas y Montes del Ministerio de Fomento, a partir de los informes elaborados por los ingenieros de montes de los distritos forestales y de las propuestas recabadas por los mismos.

En efecto, el Real Decreto de 23 de febrero de 1917 encomendó a tales ingenieros confeccionar «una relación de los sitios más notables de sus respectivas demarcaciones» atendiendo a las dos figuras principales posibles de protección recogidas en el mismo ${ }^{17}$. De un lado, los lugares que «por lo extraordinario de sus condiciones naturales o por la aureola que pueda prestarles la Historia, la Religión o la leyenda merecieran la declaración de Sitio Nacional»; de otro, aquellos otros que «no ya por lo notable o sobresaliente de sus condiciones naturales, sino por lo excepcional y completo de las mismas», merecieran el rango de Parques Nacionales. Asimismo, el Real Decreto invitaba a «las Sociedades de Amigos del Árbol, Turismo, Excursionistas y similares, y a cuantos particulares se interesen por el enaltecimiento del suelo patrio» a que contribuyeran a la formación de dichas relaciones. El mismo Real Decreto creaba la Junta Central de Parques Nacionales, que se convertiría en el organismo rector de la política conservacionista en España hasta 1931, y a la que dicha disposición atribuía como primera función la de examinar los informes y propuestas de sitios notables que se recibieran, así como proponer al Gobierno, en su caso, la creación de Parques y Sitios Nacionales.

Como ya pusiera de manifiesto Rafael Mata a partir del análisis de una buena parte de los expedientes reunidos en respuesta al citado Real Decreto, junto a los criterios estrictamente naturales (que, en consonancia con el protagonismo de los ingenieros de montes, fueron, sin duda, preeminentes), las relaciones de «Sitios Notables» incorporaron con frecuencia las citadas consideraciones de carácter religioso, histórico o legendario, que, en opinión del citado autor, «impregnan de profundo conservadurismo un buen número de proyectos ${ }^{18}$. Del más de medio centenar de Sitios inventariados en los meses

17 Gaceta de Madrid de 24 de febrero de 1917: 461.

18 MATA, 1992, vol. 2: 1072. 
siguientes a la publicación del Real Decreto (76 según el listado más completo disponible al respecto, reproducido por Alfonso Mulero ${ }^{19}$ ), muchos reúnen inequívocamente, en mayor o menor grado, este tipo de valores, cuyo peso efectivo en el conjunto de los informes remitidos desde los distritos forestales exigiría un análisis mucho más detenido del que hasta el momento he podido efectuar $^{20}$.

Pero sin duda el ejemplo más destacado de la importancia que tuvieron los valores simbólicos de carácter identitario en los inicios de la conservación de la naturaleza y del paisaje en España, así como en la declaración y caracterización de algunos de los primeros espacios protegidos del país, lo constituye el Parque Nacional de la Montaña de Covadonga. Más allá del parque natural, Covadonga representa, de hecho, de manera ejemplar, la valoración de ciertos paisajes como símbolos de la historia y la identidad nacionales. Se trata, podría decirse, no sólo de un lugar de memoria, sino de un "paisaje nacional» y «nacionalista»; un paisaje impregnado de valores simbólicos identitarios que explican su patrimonialización, su transformación material moderna y su conversión en uno de los destinos turísticos más importantes del norte de España. Como veremos a continuación, esos valores simbólicos se asocian de manera estrecha y principal con elementos históricos y religiosos (algunos de ellos puramente míticos y legendarios), pero también con otros valores, como los estéticos y naturalistas. Unos y otros serán en cierto modo institucionalizados con la declaración del Parque Nacional, que en la práctica vino a coronar un proceso de valoración patrimonial y simbólica iniciado, en lo sustancial, a mediados del siglo XIX, y no exento de disputas intelectuales e ideológicas importantes, a las que me referiré en la tercera parte del trabajo.

19 MULERO, 2002: 23-25.

20 Hasta hace pocos años, los expedientes formados a partir del Real Decreto de 23 de febrero de 1917, sobre los que trabajara, a comienzos del decenio de 1990, Rafael Mata, se conservaban en el archivo administrativo de la sede central del Servicio de Parques Nacionales del antiguo ICONA (hoy Organismo Autónomo de Parques Nacionales), sita en Madrid. Con el traslado, en 2007, de dicha sede a otro local madrileño se produjo también el traslado de la mayor parte de los fondos del citado archivo a un almacén emplazado en la Comunidad Autónoma de La Rioja, cuyo acceso al público permanece cerrado. Lamentablemente, las gestiones que efectué en 2009 a través del Fondo Documental del Monte (organismo responsable, dentro del actual Ministerio del Medio Ambiente y del Medio Rural y Marino, de custodiar los fondos del antiguo archivo del ICONA) para localizar dichos expedientes resultaron infructuosas. 


\section{COVADONGA: DE PAISAJE DE MEMORIA A PARQUE NACIONAL 21}

\section{Topografías patrióticas: mitificación y sacralización del paisaje de Covadonga}

Aunque la valoración de la batalla acontecida en torno al año 718, en las proximidades de la cueva de Covadonga, entre cristianos y musulmanes, como hito fundamental en la conformación histórica de España se remonta a las crónicas medievales y fue un tema recurrente en las historias generales del país desde la época moderna ${ }^{22}$, la conversión de la célebre cueva, de su santuario y, más ampliamente, del paisaje de los Picos de Europa en uno de los lugares de memoria canónicos y más importantes en las definiciones contemporáneas de la identidad nacional arranca, como es sabido, con el discurso historiográfico decimonónico.

Es, sobre todo, la historiografía liberal de signo moderado, sintetizada, de manera ejemplar, en la Historia de España de Modesto Lafuente, publicada en veintinueve volúmenes entre 1850 y 1867, la que otorgará al episodio un carácter eminentemente patriótico, al considerarlo como acto fundador de la Reconquista, término que no aparece de hecho hasta finales del siglo XVIII y que, a partir de este momento, se concibe como el principal hecho histórico diferenciador de la nación española respecto de las demás naciones europeas $^{23}$. En este mismo sentido, Asturias aparecerá como la cuna de una nueva nacionalidad (o como lugar de refundación de la nacionalidad perdida), formada por astures, godos e hispano-romanos unidos por la religión y la patria e iniciadores de un proceso al que luego se sumarían los demás reinos cristianos; y la cueva de Covadonga, refugio de los rebeldes acaudillados por el godo Pelayo, erigido en el primer monarca de Asturias, como el recinto matriz, según palabras del propio Lafuente, de «una religión, un sacerdocio, un rey, un pueblo y una monarquía» ${ }^{24}$. En el plano político, la lectura planteada por la influyente obra de Lafuente desde la perspectiva del liberalismo moderado contribuyó a forjar uno de los principales mitos de referencia de la naciente monarquía constitucional, articulado en torno a tres elementos estre-

21 La mayoría de las cuestiones tratadas en este apartado se han desarrollado en otro trabajo efectuado por el autor junto a Nicolás Ortega: ORTEGA y GARCÍA, 2009. Desde una perspectiva parecida, centrada en la configuración de Covadonga como lugar de memoria e identidad nacional, pueden verse los trabajos de MORENO, 2004. BOYD, 2006 y 2007. CASADO, 2010: 234-239.

22 Sobre las interpretaciones historiográficas de la batalla de Covadonga, así como sobre la geografía simbólica de las "esencias patrias", utilizando la expresión de Wulf, véanse, por ejemplo, los trabajos de BESGA, 2000: 192-254. RÍOS, 28 (Madrid, 2005). WULF, 2003: 41-51.

23 RÍOS, 28 (Madrid, 2005).

24 LAFUENTE, 1869, vol. 1: 63. 
chamente entrelazados: la figura de Pelayo (como caudillo militar proclamado rey por el pueblo), el episodio de la batalla (valorado como un acto de independencia nacional ayudado por la intercesión divina) y el escenario de la misma, dominado por la "Santa Cueva" (en la que, próximos a la capilla de la Virgen, estaban enterrados los cuerpos de Pelayo y de su yerno Alfonso I, bajo cuyo reinado la monarquía asturiana se extendió considerablemente, conquistando Galicia y la ciudad de León). Un mito capaz de integrar, en el plano simbólico, al ejército y la iglesia, la soberanía nacional y el papel tutelar de la monarquía.

Al igual que otros escenarios y episodios bélicos célebres considerados emblemáticos por el nacionalismo liberal español en tanto en cuanto evocadores de la resistencia indígena contra el invasor (como Sagunto, Numancia, Bailén o el Dos de Mayo madrileño), a mediados del siglo XIX Covadonga ocupaba ya un puesto privilegiado dentro de la ilustre nómina de los lugares de memoria nacionales ${ }^{25}$. Además, la valoración romántica del pasado medieval en general, y de los paisajes de montaña vinculados históricamente a ese pasado, en el que muchos de los nacionalismos decimonónicos - estatales o subestatales - situarían las raíces de la propia nacionalidad, reforzaría considerablemente dicha interpretación. Los paisajes evocadores de la Reconquista y del surgimiento de los distintos reinos cristianos, ilustrativos de la simbiosis entre los valores religiosos y los nacionales, ocupan en este sentido un lugar privilegiado en el imaginario regionalista o nacionalista del momento, en especial entre las corrientes de carácter tradicionalista y conservador. Aunque los referentes identitarios de tales paisajes puedan variar según las regiones y las sensibilidades nacionales respectivas, la valoración de Covadonga y de los Picos de Europa en esos términos guarda, como es sabido, paralelismos y semejanzas evidentes con la de ámbitos tales como el Pirineo catalán, y, dentro de éste, con el Canigó; la Cordillera Costero-Catalana, con Montserrat ${ }^{26}$; $\mathrm{y}$, sobre todo, como veremos más adelante, el Pirineo aragonés, con el antiguo monasterio de San Juan de la Peña, denominado por algunos autores de la época «la Covadonga de Aragón».

Como rezaba, precisamente, el informe de la Real Academia de la Historia anexo a la disposición legal por la que se declaraba dicho monasterio Monumento Nacional, «Covadonga sintetiza la restauración cantábrica como San Juan de la Peña la pirenaica ${ }^{27}$. Cuando, por Real Orden de 12 de abril de 1876, el moderado Francisco Queipo de Llano, Ministro de Fomento y diputado en Cortes por la provincia de Oviedo, solicitaba formalmente a dicha Academia su dictamen sobre si «el venerado Santuario de Covadonga, cuna

25 PÉREZ, 2007.

26 NOGUÉ, 2005.

27 Real Orden de 13 de junio de 1880 (Gaceta de Madrid de 15 de julio). 
de nuestra independencia», debía ser declarado monumento nacional, el mito estaba lo suficientemente asentado como para adquirir su primer reconocimiento legal. Así, el informe evacuado por la Academia, recogido en la Real Orden de 19 de abril de 1884, por la que se declaraba la Colegiata de Nuestra Señora de Covadonga (o de San Fernando) monumento nacional, apuntaba de inicio que tal declaración estaba «prejuzgada»:

Porque aun prescindiendo de los motivos que pudieran alegar esta Academia y la de Bellas Artes de San Fernando para solicitarla si el Gobierno mismo no la hubiese anunciado, ¿qué corazón español podrá permanecer indiferente a la perpetuación de un monumento en el que se vinculan los recuerdos del hecho memorable que puso término a la mayor cuita y dio comienzo a la mayor gloria de nuestra patria? ${ }^{28}$.

En realidad, como escenario histórico, como teatro donde según el grueso de la historiografía hegemónica del Estado liberal había tenido lugar el principio del Reino astur y, con éste, de la Reconquista y de la nación española, Covadonga comprendía, ya en el siglo XIX, mucho más que la cueva del Monte Auseva. Comprendía también su entorno próximo, y en especial el itinerario, de unos ocho kilómetros y medio, entre la villa de Cangas de Onís y el Monte Auseva, la vía de entrada natural a través del valle de Cangas y la más transitada y cómoda para acceder al santuario. Punteado por una densa serie de lugares asociados estrechamente - ya por la leyenda, ya por los hechos históricos probados - a la memoria de la batalla y de los primeros años del reino astur, este itinerario se fue convirtiendo, en especial a partir de mediados del XIX, en una suerte de «ruta histórica», en el sentido moderno y turístico de este concepto. Más aún, para ciertos turistas y viajeros cultos de la época, la experiencia de aproximarse a Covadonga por la citada ruta se asimilaba - como apuntara Carmen Morales - a una especie de «peregrinación patriótica ${ }^{29}$. A través de las iglesias, campos de batalla u otros lugares asociados a la memoria de la Reconquista que jalonaban ese camino desde Cangas de Onís hasta la cueva (incluyendo, entre otros hitos, la Vega de Santa Cruz, el Campo de la Jura o el Campo de Repelayo), el viajero no sólo podía evocar más fácilmente la historia de aquellos tiempos, sino que también iba tomando conciencia gradual de la trascendencia simbólica del célebre santuario, coronación y meta de esa peculiar peregrinación. En «aquel romántico sitio cubierto con las huellas de mil héroes - escribía en tal sentido Francisco de Paula Mellado, al recordar su viaje Covadonga- (...) cada tronco de árbol, cada peñasco, cada trozo de terreno es un monumento histórico y el recuerdo

28 Gaceta de Madrid de 2 de mayo de 1884: 288-289.

29 MORALES SARO, 1989. 
de una hazaña ${ }^{30}$. Y el informe ya citado de la Academia de la Historia sobre la declaración de la Colegiata de Covadonga como monumento nacional concluía con una recomendación explícita en este sentido, que no llegó a ser aplicada: la de que «la protección del Estado» no se redujera solo a dicho monumento, sino que también:

debía extenderse a todo cuanto en aquellos contornos dentro del radio de dos leguas dura todavía, recordando que tuvo allí D. Pelayo en Covadonga su lauro, en Cangas de Onís su corte, y en Abamia su sepulcro ${ }^{31}$.

La contemplación de la Santa Cueva, el punto final de ese itinerario por los escenarios de lo que la Real Academia de la Historia llamara, en el mismo informe, «la más trascendental victoria que registran los anales de la España cristiana», no solía dejar indiferente al viajero de la época, conmovido por un paisaje que encajaba plenamente en el gusto romántico y que se percibía como una fusión admirable de naturaleza, historia y religión.

Lo que existe en Covadonga — recogía, por ejemplo, el Diccionario de Pascual Madoz, apoyado en las informaciones de Nicolás Cástor de Caunedo- es incompleto y desunido, pero el todo es magnífico; el arte presta variedad al cuadro, y con su cascada y cauce artificial, lucha con la naturaleza sin encubrir ninguna de sus bellezas. Efectivamente, la primera vista de Covadonga desde el camino real sorprende y admira: una montaña cuya corona de hayas y encinas se eleva 4.000 pies sobre el espectador; en su centro, la peña y cueva-longa, sitio de milagros y grandezas históricas, y en ella la capilla de la Virgen, cuyo asiento muestra de noche un farol, solo en aquella oscuridad; más abajo la obra del hombre, una especie de hermoso castillo por cuya puerta sale un río que forma al caer un velo plateado; aún más cerca un puente cubierto todo de hiedra sembrada de campanillas blancas; por último, otra cascada natural, la más hermosa de todas y cuya espuma casi salpica al viajero; al pie de la peña la colegiata, edificio humilde, pero de líneas bizantinas: todo esto se presenta al primer golpe de vista, en el que por cierto abarca todo cuanto hay de notable en el santuario. En octubre de 1846 dibujó el Sr. Villamil (sic.) esta perspectiva, y dijo que muchos creerían ser un capricho, porque la realidad parece increíble ${ }^{32}$.

Con la identificación de Covadonga y de su paisaje como lugar de memoria y mito nacional fundacional comenzaron otros procesos que, en parte, contribuyeron a realzar el carácter simbólico del sitio y en parte también a desvirtuar algunos de sus valores y significados previos, introduciendo transformaciones decisivas en el paisaje. El período comprendido entre 1872 (en que comenzó

30 MELLADO, 1849-1851: 130.

31 Real Orden de 19 de abril de 1884 (Gaceta de Madrid del 2 de mayo: 289).

32 MADOZ, 1845-1850, t. VII: 160-162 (artículo «Covadonga"). 
la restauración arquitectónica moderna del santuario) y 1918 (fecha de la celebración del XII Centenario y de la declaración del Parque Nacional) resultó decisivo en ese sentido y estableció las bases de la puesta en valor turística de Covadonga y, más ampliamente, del sector occidental de los Picos de Europa. En ese período se produjo, en especial, el «renacimiento monumental» de Covadonga, bajo el liderazgo del cabildo de la Colegiata (y, dentro de éste, de Máximo de la Vega, canónigo de Covadonga entre 1867 y 1896) y de los obispos de Oviedo Benito Sanz y Forés (que estuvo al frente de la diócesis ovetense entre 1868 y 1881) y Ramón Martínez Vigil (que la presidió de 1884 a 1901).

El primero de ellos concibió e impulsó un ambicioso programa de reformas, amparado por diversos privilegios papales, dirigido a engrandecer el sitio y convertirlo en un referente simbólico de la devoción mariana y en general católica en España. Durante su obispado se construyó una nueva capilla en la cueva (el llamado Camarín de la Virgen); se restauró la Colegiata y se amplió la misma, al tiempo que se iniciaron los trámites para declararla monumento nacional; y comenzó, en 1877, meses después de una visita oficial de Alfonso XII, la construcción de la moderna basílica, elemento central de la renovación monumental del sitio. Por lo que toca al papel desempeñado por Martínez Vigil, su labor fue decisiva para continuar y concluir las obras de la basílica, consagrada, finalmente, en 1901. Bajo su obispado se concretó también, en abril de 1884, la declaración de monumento nacional de la Colegiata, impulsada y aprobada, en última instancia, por Alejandro Pidal y Mon, a la sazón Ministro de Fomento, principal hombre fuerte de la política asturiana y representante de las tendencias más católicas y conservadoras del gobierno de Cánovas.

Como algunos autores han puesto de manifiesto ${ }^{33}$, la restauración monumental de Covadonga contó, en efecto, con la connivencia o el apoyo activo de los gobiernos conservadores de la Restauración, interesados en atraer a dichas tendencias a la causa de la monarquía, en un contexto religioso, como fue el del pontificado de León XIII (1878-1903), marcado por un notorio repunte internacional de la actividad de la iglesia y de las corrientes político-ideológicas católico-tradicionalistas, como la liderada, en España, por el propio Pidal y Mon. En medio de ese clima que María Victoria López-Cordón ha denominado de «apoteosis patriótico-religiosa» y que rodeó la construcción del nuevo santuario, así como otros fastos y conmemoraciones de signo parecido, hasta alguien tan crítico con el catolicismo ortodoxo como Clarín llegó a escribir:

Covadonga tiene que representar dos grandes cosas: un gran patriotismo, el español, y una gran fe, la católica de los españoles, que por su fe y su patria lucharon

33 En especial: LÓPEZ CORDÓN, 1990. LÓPEZ SUÁREZ, 2001. BOYD, 2006 y 2007. 
en Covadonga. Una catedral es el mejor monumento en estos riscos, altares de la patria $^{34}$.

La mejora considerable de los accesos a la zona entre 1884 (año a partir del cual quedó abierto el tránsito ferroviario entre la Meseta y Asturias, por el puerto de Pajares) y 1908 (en que se inauguró el tranvía a vapor entre la localidad de Arriondas y el campo de Repelayo, en las estribaciones del Santuario, que permitía enlazar, en Arriondas, con las líneas de ferrocarril que cubrían el trayecto entre Oviedo y Santander) impulsaría de modo decisivo la puesta en valor turística del lugar, que la inauguración del Parque Nacional vendría, en buena medida, a completar.

\section{«LA NUEVA RECONQUISTA»: NATURALEZA E HISTORIA EN LA CREACIÓN DEL Parque Nacional de la Montaña de Covadonga}

En una intervención pronunciada ante el Senado el 4 de diciembre de 1916, una semana después de haber sido sancionada la Ley de Creación de Parques Nacionales, comentó Pedro Pidal que la iniciativa de que el primer Parque Nacional creado en España fuera el de la Montaña de Covadonga había partido de Alfonso XIII, quien, en 1915, en el transcurso de una visita efectuada al santuario junto a la reina Victoria Eugenia y «emocionado por el espectáculo» que ofrecían «los contrafuertes de los Picos de Europa» «desde la terraza de la basílica, habría expresado públicamente este deseo» ${ }^{35}$. En la misma intervención, Pidal, Marqués de Villaviciosa y senador vitalicio desde 1914, propuso, en presencia del Conde de Romanones, a la sazón presidente del Consejo de Ministros, llevar a cabo ese deseo, sumándose a las propuestas planteadas coetáneamente por varios parlamentarios asturianos para conmemorar oficialmente el XII Centenario de la Batalla de Covadonga e incluir la creación del Parque Nacional en el programa de dicha conmemoración ${ }^{36}$.

El 23 de febrero de 1917 se creaba, como vimos, mediante el Real Decreto ya mencionado, la Junta Central de Parques Nacionales, de la que Pidal fue nombrado Vicepresidente, además de ser designado Comisario General de Parques Nacionales, cargo que ostentaría hasta marzo de 1935. El 13 de mayo de 1918 el diputado Félix Suárez Inclán, en representación de varios diputados asturianos, presentó en el Congreso la Proposición de Ley «estableciendo la manera de conmemorar en Asturias el XII Centenario de la Batalla de Covadonga», cuyo artículo 2 disponía declarar «Parque nacional el Parque natu-

\footnotetext{
34 CLARÍN, 1893. Cfr. en LÓPEZ CORDÓN, 1990: 94-95.

35 CANELLA, 1918.

36 CANELLA, 1918: 197-293.
} 
ral de la Montaña de Covadonga, del macizo en extremo pintoresco de Peña Santa, teatro de las hazañas de Pelayo en la Reconquista» ${ }^{37}$. Y el 22 de julio de ese mismo año, tras la preceptiva aprobación de las Cortes, el rey sancionó la ley por la que se disponían diferentes medidas destinadas a la conmemoración del citado Centenario (que en la ley se denominaba «de la Reconquista») $)^{38}$. El artículo $1^{\circ}$ de esta ley establecía que «Covadonga será objeto de especial protección por parte del Estado», y el $2^{\circ}$ declaraba el macizo de Peña Santa «Parque Nacional de la Montaña de Covadonga». Los límites de éste fueron fijados el 16 de agosto siguiente, en el mismo Real Decreto que disponía la creación y establecía los límites del Parque Nacional del Valle de Orde$\mathrm{sa}^{39}$.

Al margen de que la iniciativa de creación del Parque Nacional de Covadonga pudiera haber partido del deseo del rey y que la tramitación formal del procedimiento fuera protagonizada por los parlamentarios asturianos, el papel desempeñado por el Marqués de Villaviciosa en el proceso resultó, en cualquier caso, evidente y decisivo. Una parte notable del celo puesto por Pidal en esta declaración deriva como es sabido de su amistad personal con el rey y de sus vínculos familiares y afectivos con la región asturiana, con los Picos de Europa y con el santuario de Covadonga ${ }^{40}$. Alpinista destacado (en 1904 había conquistado la cima del Naranjo de Bulnes, hito fundamental en la historia del montañismo en España, y en 1906 escaló el Cervino), Pedro Pidal y Bernaldo de Quirós (1869-1941) fue en su época uno de los principales amantes y conocedores de los Picos de Europa, a los que consagró una de las primeras guías de la zona, escrita en compañía del célebre montañero José Fernández Zabala ${ }^{41}$. Gran aficionado a la caza, afición que compartió con Alfonso XIII, a quien acompañó en varias cacerías en las montañas cantábricas (1905, 19121920 y 1926), en 1905 Pidal había promovido ya, de hecho, la creación del Coto Real de los Picos de Europa con la intención de proteger el rebeco, medida considerada por Casado, junto con el paralelo Coto Real de la Sierra de Gredos, declarado para la protección de la cabra montesa, «la primera operación llevada a cabo en España con una orientación genuinamente conservacionista ${ }^{42}$. Profundamente católico, monárquico y conservador, también le unían vínculos familiares especiales con el santuario de Covadon-

37 Diario de las Sesiones de Cortes de 13 de mayo de 1918, apéndice $3^{\circ}$. La proposición incluía un programa de actividades mucho más amplio que el que finalmente se llevó a cabo.

38 Gaceta de Madrid de 24 de julio de 1918. El expediente de esta Ley se conserva en el Archivo del Congreso de los Diputados (Legajo 441 n.4), aunque contiene escasa documentación.

39 Gaceta de Madrid de 18 de agosto de 1918.

40 FERNÁNDEZ, 2004.

41 PIDAL y ZABALA, 1918.

42 CASADO, 2010: 231. 
ga, donde fueron enterrados su abuelo Pedro José Pidal y Carniado, en 1865, y su padre, el citado Alejandro Pidal y Mon, en 1913. Él mismo sería enterrado inicialmente allí, en el panteón familiar que los Pidal poseían en la Colegiata, antes de que sus restos mortales fueran trasladados, en septiembre de 1949, al Mirador de Ordiales, de acuerdo con su deseo testamentario.

Pero, más allá de tales vínculos, aficiones y precedentes, lo que interesa especialmente aquí, en relación con el tema objeto de este trabajo, es la concepción que Pidal tenía del paisaje, de los Parques Nacionales en general y del Parque Nacional de Covadonga en particular, sintetizada en diversos escritos y discursos ${ }^{43}$. Dos son, sobre todo, aparte de los beneficios de tipo económico derivados del turismo, los argumentos que maneja Pidal en su defensa de la creación del Parque Nacional de Covadonga: su belleza desde el punto de vista estético y su importancia simbólica en relación con las claves que para él conforman la identidad nacional española, así como con el problema de la deforestación, que considera uno de los grandes males del país. Desde el punto de vista estético, son claras sus preferencias por los paisajes verdes, montañosos y arbolados; su gusto por el canon romántico y alpino, de postal suiza, y la naturaleza agreste, majestuosa y salvaje de los primeros Parques Nacionales de los Estados Unidos de América (Yellowstone y Yosemite), que conocía personalmente muy bien. Tales preferencias guían en buena medida la creación de los dos primeros parques nacionales españoles: el de Ordesa, que Pidal denominaba «un Parque de valle», «selvático», «de recogimiento»; y el de Covadonga, que, en el preámbulo que había redactado el autor para el Real Decreto de 16 de agosto de 1918, y que finalmente no fue publicado en el mismo, describía como:

un Parque de Montaña, de excursiones, de vistas, de horizontes, de contemplación de rocas y de abismos, de Picos esbeltos, atrevidos, que rebasan las nubes y se elevan sobre el verde infinito de praderías inclinadas, vertientes sobre el precipicio, de que emergen los bosques, que brotan por las gargantas de ríos, cual el Cares y el Dobra, que se deslizan y despeñan por los desfiladeros más abruptos, solitarios y salvajes, [por donde pueden] verse cientos de rebecos corriendo y saltando por entre acantilados incomprensibles y abismos de belleza insuperable ${ }^{44}$.

Esa preferencia estética se une, en el pensamiento de Pidal, a otros valores de tipo moral y patriótico: crear Parques Nacionales, proteger y conservar la naturaleza y los paisajes de las montañas, «con su belleza eterna» ${ }^{45}$, recorrerlos, estudiarlos, experimentar y vencer sus dificultades, no sólo vigoriza y

43 Entre las obras de Pidal más esclarecedoras a los efectos del tema objeto de este trabajo, cabe citar: PIDAL, 1916; 1917; 1919.

44 PIDAL, 1919: 57.

45 PIDAL, 1919: 54. 
forma moralmente al individuo, sino que además «hermosea la patria» y es uno de los mejores medios de inculcar, en los jóvenes, el amor a la misma:

Para hacer almas grandes y cuerpos fuertes, energías, salud y patriotismo — escribía Pidal en El Imparcial de 7 de agosto de 1917-, nada como contemplar los grandes paisajes de la patria, nada como empeñarse en alcanzarlos y conseguirlo, nada como señalar un sitio lleno de vistas y de cumbres vírgenes innominadas, para que la juventud las escale, domine y denomine ${ }^{46}$.

Los Parques nacionales españoles en general, y el Parque Nacional de Covadonga en particular, encierran y deben ser, además, para Pidal, símbolos fundamentales, no sólo del pasado y el origen de la nación, así como de sus esencias, sino también de la necesaria regeneración política y moral del país, de las políticas que debían emprenderse para paliar algunos de sus principales males. Uno de esos males principales, sobre el que vuelve continuamente Pidal en sintonía con el pensamiento regeneracionista (y en particular con las ideas de Joaquín Costa), es la deforestación, que no sólo afea el aspecto del país, sino que además, unida a las características del roquedo, del relieve y del clima peninsular, estimula la erosión y es causa de pobreza, emigración y decadencia: «Los árboles — defendía Pidal- son los que hacen hermoso, interesante el Paisaje» ${ }^{47}$. «Un país sin árboles es un país muerto o que se muere, país feo, de una fealdad horrible, país del que huye todo el mundo» ${ }^{48}$. De ahí que, como apunta en otro lugar, piense que «la guerra a los árboles es la guerra a la nación, porque los árboles son los pilares de la patria» ${ }^{49}$. Y que la creación de Parques Nacionales, por lo que supone en términos de protección del arbolado y de «las joyas naturales» del país, simbolizara para él, como afirmó en el Senado, el inicio de «una nueva Reconquista»:

Y siendo [los Parques Nacionales] de España — afirmaba Pidal ante el Senado- (...) tendrán forzosamente el carácter de Reconquista; de Reconquista sí, del territorio nacional, que si antes fueron los árabes los que nos conquistaron, hoy son las arideces las que nos conquistan ${ }^{50}$.

La intencionalidad de la analogía en el contexto de la discusión de la ley de creación de Parques Nacionales era obvia y atribuía al Parque Nacional de la Montaña de Covadonga, el primero que debía crearse, un valor simbólico añadido: el de encabezar esa «Nueva Reconquista de España: la expulsión de

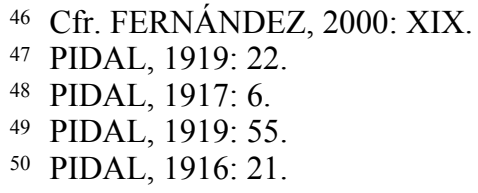


las arideces del suelo de la Patria» ${ }^{51}$. En ese mismo orden de analogías, Pidal se refería al Conde de Romanones como «el Segundo Pelayo», que «iniciará la segunda Reconquista de España si (...) hace que el Gobierno declare a Covadonga, a la Montaña de Covadonga, a los Picos de Europa, el primer Parque Nacional de España» ${ }^{52}$. Pero, por encima de todos esos valores, Covadonga reunía, para Pidal, una triple condición simbólica: la de ser «santuario de la Naturaleza, santuario de la Religión y santuario de la Historia (...) el principal santuario de la historia patria» ${ }^{53}$. Allí, afirmaba en el Senado el 8 de julio de 1916, «Pelayo (...) inició nada menos que la existencia de España, hecho el más fecundo y glorioso de la historia patria» ${ }^{54}$.

Allí se detuvieron - escribía en el preámbulo legal antes citado - las legiones del César, y allí quedó aplastado el poder de la Media Luna, bastando una ligera contemplación del paisaje, una mera asomada a los ríos o a los riscos, para darse cuenta exacta de los acontecimientos de la historia ${ }^{55}$.

\section{¿Qué Paisajes PRoteger Y PaRa Qué naCión? PARQues NATURALeS Y DisPUTAS IDENTITARIAS EN LA ESPAÑa DE ALFONSO XIII}

La creación del Parque Nacional de la Montaña de Covadonga debe entenderse, pues, en buena medida, en este contexto de afirmación patrióticoreligiosa y de promoción turística de la zona, que tuvo en el argumento histórico su punto de partida, en el santuario su principal símbolo y polo de atracción, y en los sectores católicos y conservadores sus mayores (que no únicos) valedores políticos e ideológicos. Ello no significa, obviamente, que en la declaración y en el trazado del Parque no pesaran otros valores, lecturas y objetivos, del mismo modo que participaron otros grupos y corrientes político-ideológicos, con planteamientos no siempre acordes con los anteriormente citados. Como en otros muchos casos, ambos - la declaración y el trazadose inscriben en un movimiento cultural más amplio de descubrimiento y revaloración de los Picos de Europa y de los paisajes de montaña en general, en que también participan, convergen y, en ocasiones, chocan, el excursionismo (en sus múltiples dimensiones), el naturalismo y la investigación científica, la afición a la caza, el alpinismo acrobático y deportivo, o las representaciones artísticas y literarias ${ }^{56}$. Pero desde el punto de vista simbólico y patrimonial,

51 PIDAL, 1917: 12.

52 Discurso reproducido en CANELLA, 1918: 232-233.

53 Cfr. CANELLA, 1918: 231.

54 Cfr. CANELLA, 1918: 220.

55 PIDAL, 1919: 57.

56 Sobre el proceso de descubrimiento cultural de los Picos de Europa y los orígenes y 
Covadonga significó, sobre todo, un paisaje valorado como el escenario histórico de un episodio considerado fundacional o cuando menos determinante, en aquel entonces, para la historia nacional.

La propia declaración del Parque Nacional, concebida, según hemos visto, como un apartado más de la Ley de Conmemoración del XII Centenario de la batalla de Covadonga; el nombre mismo del Parque y los límites geográficos acordados para éste, que perdurarían hasta 199557; y, más aún, los discursos pronunciados durante su inauguración, celebrada el 8 de septiembre de 1918, el día de la festividad de la Virgen de Covadonga y como broche de los actos del citado Centenario, pusieron de manifiesto la importancia otorgada al paisaje-escenario, o al paisaje-teatro, por encima incluso de otros valores. Si, con ocasión de dicha inauguración, a la que asistió una nutrida representación institucional (que incluía, además de a los reyes, al cardenal Guisasola, Primado de España, y al Ministro de Fomento, Francisco Cambó), el Marqués de Villaviciosa se refería a Covadonga como «el teatro de las hazañas de Pelayo», y a «los esplendores de la Naturaleza» como «el mejor museo a los sentimientos de la Religión y a los recuerdos de la Historia» ${ }^{58}$, el vocal ingeniero de montes de la Junta Central de Parques Nacionales, Andrés Avelino de Armenteras, afirmaba que:

Aunque por rarísima excepción, lo importante, a veces, en los montes, no es la belleza que ostentan ni la riqueza que suponen, sino el hecho de que constituyan el más genuino recuerdo de los orígenes de un pueblo y el vivo testigo de sus tradiciones (...) La tierra que pisó Pelayo, las rocas que escalaron sus huestes y los árboles, hijos de aquellos a cuya sombra pelearon, son algo más que una tierra que pueda labrarse, unas rocas que puedan convertirse en canteras y unos árboles que han de cortarse cuando alcancen su máxima producción, porque su principal valor no estriba en su tasación real y positiva, sino en la obra que perduran: son algo así como una reliquia nacional $(\ldots)^{59}$.

avatares del Parque Nacional, pueden verse los trabajos de FERNÁNDEZ y PRADAS, 2000, t. II: 21-128. CASTAÑÓN y FROCHOSO, 2007. GONZÁLEZ y SERRANO, 2007.

57 El Parque Nacional de la Montaña de Covadonga o Peña Santa creado en 1918 ocupó una superficie de 16.925 ha, situadas íntegramente en la provincia de Oviedo. La Ley 16/1995 de 20 de mayo, además de sustituir la denominación original del Parque por la de Picos de Europa, amplió considerablemente su superficie, que, compartida por las Comunidades Autónomas de Asturias, Cantabria y Castilla y León, comprende 65.660 ha. Repárese en que el informe del ingeniero-jefe del distrito forestal de León remitido en respuesta al citado Real Decreto de 23 de febrero de 1917 había propuesto ya la creación de un Parque Nacional dentro de dicha provincia con el nombre de Picos de Europa, como ha quedado recogido en los estudios de MATA, 1992: 1072. FERNÁNDEZ y PRADAS, 2000, t. II: 22-23.

58 «La inauguración del primer Parque Nacional de España», Revista de Montes, 1000 (Madrid, 15 de septiembre de 1918): 614-619, pág. 614.

59 «La inauguración del primer Parque Nacional de España», Revista de Montes, 1000 (Madrid, 15 de septiembre de 1918): 615. 
La intervención de Alfonso XIII al término de dichos actos inaugurales sintetizó todavía más la significación nacionalista de la declaración del Parque:

Vamos a hacer algo completamente único en el mundo: unir el arte de la Naturaleza a la Historia en el sitio del nacimiento de una nación. Eso no se hace con dinero, sobre todo si lleva el sello de doce siglos. Y eso es Covadonga: España, la Virgen, el Arte, la Historia y la Naturaleza ${ }^{60}$.

Pero a la altura de 1918 era evidente que los argumentos simbólicos e ideológicos que sustentaban la creación del Parque, empezando por la propia concepción nacional a que se asociaba, distaban de ser unánimes e indiscutidos dentro del Estado y de la misma región asturiana. Por lo pronto, y como ha acertado a demostrar Carolyn Boyd, la conversión del paisaje de Covadonga en un lugar de memoria e identidad colectiva en los últimos decenios del siglo XIX y los primeros del XX fue objeto de diversas lecturas, y hasta de disputas ideológicas entre, por un lado, la Iglesia católica y las élites conservadoras locales, entre las cuales se significó particularmente la familia Pidal, y, por otro lado, determinados sectores locales de orientación liberalreformista, europeísta o incluso progresista, vinculados intelectualmente a la Universidad de Oviedo. Frente a los planteamientos de los primeros, estos sectores liberal-reformistas defendieron una interpretación alternativa del mito y del lugar más acorde con sus deseos modernizadores de la región y con los valores morales seculares que, según pensaban, eran o debían ser inherentes a la identidad nacional ${ }^{61}$. Los debates sobre la forma de celebrar el XII Centenario de la batalla de Covadonga ejemplificaron de forma palmaria esas disputas por la memoria del episodio (y, en relación con ella, por la organización simbólica del paisaje del real sitio) en las que, como puede deducirse fácilmente a partir de lo visto, acabaron imponiéndose los sectores católicotradicionalistas.

Pero además la declaración del Parque Nacional y, más ampliamente la conmemoración del XII Centenario de la Batalla de Covadonga, se entremezclaron, de forma significativa, con los debates sobre la cuestión regional y la organización territorial del país. En el contexto del ascenso social y electoral progresivo de los regionalismos y nacionalismos periféricos, los primeros pasos de la política de protección de la naturaleza en España se vieron envueltos desde el principio en las disputas identitarias de carácter territorial, comenzando por el mismo uso del adjetivo «nacional» para los Parques que se

60 «La inauguración del primer Parque Nacional de España», Revista de Montes, 1000 (Madrid, 15 de septiembre de 1918): 618-619.

61 BOYD, 2006: 167-178. 
proyectaba crear. En efecto, en el marco del III Congreso Excursionista Catalán, celebrado en Tarragona en abril de 1914, y retomando la propuesta formulada en 1902 por el ingeniero de montes Rafael Puig i Valls, persona próxima ideológicamente al catalanismo moderado, de crear un «Parque Nacional de la Montaña de Montserrat», la barcelonesa Sociedad Cívica La Ciudad Jardín había solicitado a la naciente Mancomunidad catalana la creación de «Parques Nacionales de Cataluña» ${ }^{62}$. Propuesta que sería bien recibida, aunque con una corrección terminológica contundente y sin resultados concretos, pocos años después en el Senado por el propio Marqués de Villaviciosa, quien, tras felicitar a dicha Sociedad Cívica «por haber puesto sobre el tapete la cuestión de los Parques Nacionales», matizó que:

antes que los Parques Nacionales de Cataluña, que al ser de una región ya no podrían llamarse «Nacionales», y esto es evidente, debemos todos crear los Parques Nacionales de España. Siendo de España, serán también de Cataluña y de Andalucía, de Galicia y de Murcia, de Baleares y Canarias, sea cual fuere el punto del territorio nacional, peninsular o extrapeninsular en que radiquen ${ }^{63}$.

Y es que, como había insistido en las Cortes el historiador y senador asturiano Fermín Canella, la conmemoración del citado Centenario cumplía, junto a las ya señaladas, una importante función simbólica: representar un doble patriotismo - asturiano y nacional» (o español)—, y movilizar dicho patriotismo por todos los ámbitos de la Península «en estos tiempos de dudas y vacilaciones, egoísmos e indiferencias, que quieren abrir una brecha en nuestra nacionalidad o la ponen al borde del precipicio, por culpa de todos» ${ }^{64}$. Recientes todavía las agrias discusiones que había provocado en las Cortes la creación, en marzo de 1914, de la Mancomunidad de Cataluña, percibida por un importante sector de la clase política y de la opinión pública españolas de la época como un estímulo para las demandas regionalistas, Canella concebía la celebración de este Centenario como un acto simbólico de afirmación de la unidad nacional. Pues, según exponía ante el Senado el 4 de diciembre de 1916:

Covadonga fue punto de partida para la Unidad Nacional de España» y «significa (...) la independencia y la monarquía españolas, coronadas por la Unidad na-

62 CASADO, 2010: 244-246 y 252-254. En 1917, respondiendo al llamamiento hecho por el citado Real Decreto de 23 de febrero de 1917, la misma Sociedad Cívica publicaría una lista de posibles parques para Cataluña y Baleares, que ha sido sintetizada en MATA, 1992: 1071. Y en 1922 el escritor y político Jaume Bofill i Mates, miembro de la Lliga Regionalista y conseller en la Mancomunidad de Cataluña, presentaría una moción para que ésta creara el "Parc Nacional" del Montseny.

63 Discurso pronunciado el 14 de junio de 1916, en defensa de la proposición de ley para la creación de Parques Nacionales (PIDAL, 1916: 21, cursivas e itálicas del original).

${ }^{64}$ CANELLA, 1918: 205-206. 
cional, que ya no puede alterarse, ni siquiera discutirse, consagrada y afianzada por la historia como el dogma de la Patria ${ }^{65}$.

Un tipo de discurso que, como ha apuntado Manuel Mollá, suponía «asumir como paisajes míticos de la 'patria unida' aquellos que ya lo eran para algunos de los antiguos reinos, frente al pensamiento secesionista de los nacionalismos periféricos» ${ }^{66}$, y que operó no sólo en la declaración del Parque Nacional de la Montaña de Covadonga, sino también en la del Sitio Nacional del Monte de San Juan de la Peña, aprobada por Real Orden de 30 de octubre de 1920.

La creación de este Sitio Nacional vino precedida, de hecho, por las quejas y reivindicaciones de algunos intelectuales, eclesiásticos y políticos aragoneses molestos con el contraste entre el privilegiado trato oficial concedido a Covadonga y el abandono en que yacían los monasterios viejo y nuevo de San Juan de la Peña, el último de los cuales sufría un deterioro grave desde la exclaustración de los monjes benedictinos en 1835. Apenas cuatro días después de los pomposos actos de conmemoración del XII Centenario de la Batalla, el célebre periodista zaragozano Mariano de Cavia publicó en el diario El Sol una carta en que censuraba a Alfonso XIII —o como el autor prefería llamar, Alfonso VI de Aragón - por afirmar que Covadonga era «la cuna de nuestra nacionalidad», recordándole que «la Reconquista (...) fue doble, paralela, simultánea, con sendas cunas y sendas epopeyas ad majorem Hispaniae gloriam», y que «también Aragón tiene su Covadonga (...), la otra Covadonga», sumida, pese a su condición de Monumento Nacional, «en el olvido más inicuo» y «privada de los recursos más indispensables para impedir que se desmorone» ${ }^{67}$. Para Cavia, además, el viejo monasterio pirenaico, donde fueron enterrados los fundadores del condado y del reino de Aragón y algunos monarcas navarros que reinaron en Aragón, representaba mejor que Covadonga - «cuna de la Reconquista castellana»- la idea de la Reconquista como empresa conjunta entre diversos reinos y, por añadidura, podía considerarse como «cuna real y positiva del derecho público en España».

En los días siguientes a la carta de Cavia se escribieron otros artículos con demandas similares, como los de Florencio Jardiel, deán de la catedral de Zaragoza, y Ricardo del Arco Garay, cronista de la ciudad y provincia de Huesca, secretario de la Comisión Provincial de Monumentos y miembro de las reales academias de Historia y de Bellas Artes ${ }^{68}$. Autor de una monografía sobre el Monasterio titulada, de manera harto expresiva, La Covandonga de Aragón, Del Arco proponía, en un artículo publicado en El Heraldo de Ara-

65 CANELLA, 1919: 225.

66 MOLLÁ, 73-74 (Oviedo, 2007): 164.

67 «Las dos Covadongas. La favorecida y la olvidada», El Sol, 12-IX-1912. Artículo reproducido en ARCO, 1919: 9-12.

68 ARCO, 1919. 
gón y dirigido al deán de Jaca, Dámaso Sangorrín, varias medidas para recuperar el monumento y promocionar su conocimiento. Entre ellas, y aparte de las necesarias obras de restauración y rehabilitación, se defendía asignar al monasterio un guardia oficial, construir en sus proximidades una hospedería para los visitantes, publicar un álbum-guía del monumento, mejorar los accesos por carretera al mismo y, concederle «el honorífico dictado de Sitio Nacional, como ha propuesto el ingeniero de Montes D. Enrique de las Cuevas ${ }^{69}$. En parecido sentido, el obispo de Jaca y senador por dicha provincia, Manuel de Castro Alonso, intervenía en la cámara alta en febrero de 1919 para solicitar a los ministros de Instrucción Pública y de Fomento que prestaran atención a «aquel monumento completamente olvidado, tristísimamente olvidado (...) que tiene toda la historia de España, toda la historia de las libertades aragonesas y toda la historia de los grandes tiempos de la unión nacional» ${ }^{70}$.

Como el texto de la citada Real Orden de 30 de octubre de 1920 reconocía, el Marqués de Villaviciosa, en su calidad de Comisario General de Parques Nacionales, haría suyas pronto todas estas peticiones, impulsado la declaración del Monte de San Juan de la Peña como Sitio Nacional. Apelando a unos argumentos que coincidían bien con las convicciones de Pidal, la disposición creadora del Sitio Nacional rezaba en su preámbulo:

El legendario monte Pano, cuna de la epopeya medioeval (sic.) aragonesa; enaltecido más tarde con el nombre de San Juan de la Peña, guarda entre las bellezas naturales de atractivos paisajes recuerdos históricos y sentimientos religiosos del más alto valor espiritual. El pino, el haya, el pinabete y el tilo en armoniosa mezcla con otras especies sobre un suelo de variada configuración prestan sugestivo marco a su austero Monasterio antiguo, que perpetúa una de esas tradiciones en que la poesía y la fe exaltan la piedad del pueblo y custodia en sagrado depósito los restos de ilustres Reyes de Navarra y Aragón. Sirven además estos árboles, formando espléndido bosque, de grandioso escabel a su nuevo Monasterio, que con mayores alardes de construcción y más amplias proporciones pregona en la parte alta de la montaña que también las generaciones de la edad moderna saben rendir culto a la tradición. Con razón ha sido llamado el monte de San Juan de la Peña la Covadonga aragonesa y justificado está el fervoroso entusiasmo que los hijos de aquella noble región lo veneran y han pedido que sea declarado Sitio Nacional ${ }^{71}$.

69 "Por la Covadonga Aragonesa. Lo que conviene hacer", El Heraldo de Aragón, 1-X1918 (Reproducido en ARCO, 1919: 23-27). El citado Enrique de las Cuevas era, a la sazón, el ingeniero-jefe del Distrito Forestal de Huesca. En cambio, el nombre del monasterio de San Juan de la Peña no consta en la relación de sitios notables de 1917 propuesta para la provincia de Huesca, publicada por MULERO, 2002: 23, en la que sólo figura el Cañón del Valle de Añisclo y Circo de Pineta.

70 Diario de Sesiones del Senado de 13 de febrero de 1919: 1902-1903.

71 Real Orden de 30 de octubre de 1920 (Gaceta de Madrid de 5 de noviembre: 605). En junio de 1916, Pidal había defendido, por encima de cualquier otro paisaje, la protección de las montañas, «que intensifican la vida y son el venero de energías», con argumentos tales 


\section{BALANCE Y CONSIDERACIONES FINALES: LA PROTECCIÓN DEL PAISAJE COMO REFLEJO Y VEHÍCULO DE LA NACIONALIZACIÓN ESPAÑOLA}

Los inicios de la conservación de la naturaleza y del paisaje en España estuvieron profundamente influidos por las dimensiones simbólicas de carácter identitario. Conocedores y partícipes de las coordenadas intelectuales del paisajismo moderno, los artífices de las primeras medidas conservacionistas vieron en el paisaje un orden natural conectado directamente con la presencia histórica y actual de las sociedades, así como una expresión simbólica, además de material, de la identidad colectiva de sus habitantes. Algunos de los primeros paisajes protegidos o considerados dignos de protección en España lo fueron en buena medida porque las personas que impulsaron decisivamente su conservación, empezando por Pedro Pidal, los entendieron como símbolos de las claves que según ellos constituían la identidad nacional.

Las concepciones nacionales de Pidal, fuertemente católicas y conservadoras, acentuadas por el contexto político de momento, influyeron de forma decisiva no sólo en los principios que alentaron la creación de los primeros parques naturales, sino también en los criterios con que seleccionaron y se declararon, primando ciertos ámbitos de montaña (como Covadonga y San Juan de la Peña) que, a su belleza estética e interés ambiental, unían la presencia de monumentos de carácter histórico y religioso que remitían a los orígenes de la Reconquista y, más ampliamente, al proceso de unificación política y confesional de la monarquía española. Al igual que en otros «viejos» países europeos, los paisajes nacionales institucionalizados en los primeros parques nacionales españoles aunaban indisolublemente, de acuerdo con el imaginario historiográfico dominante, la naturaleza y la historia patrias, el paisaje y la memoria histórica de la nación, localizándose en el epicentro físico y simbólico de las dos grandes «áreas nucleares» del estado, o como se decía en el lenguaje de la época, las dos principales «cunas» de la independencia nacional: la Cordillera Cantábrica y el Pirineo. Como afirmaba la exposición de motivos de una de las primeras disposiciones creadoras de los Parques Nacionales en España, firmada por el entonces Ministro de Fomento, Francisco Cambó, además de «sus bellezas forestales e hidrológicas, con las de sus ambientes y horizontes»,

como el de que «los españoles que iniciaron la Reconquista se descolgaban de los Picos de Europa y del Pirineo, de Covadonga y San Juan de la Peña» (PIDAL, 1916: 16). Y el 25 de septiembre de 1918, respondiendo a un artículo de Carmelo Pérez Barón en que solicitaba la declaración de Sitio Nacional para San Juan de la Peña, había anticipado su convicción de que «si el primer Parque Nacional fue Covadonga, el primer Sitio Nacional debe ser San Juan de la Peña» (Cfr. FERNÁNDEZ, 2004: 253-254). 
[esos] montes y valles conservan el aspecto peculiar de la Patria, en su primitivo aspecto natural, integrando los recuerdos de sus orígenes, siendo el vivo testigo de sus tradiciones $(\ldots)^{72}$.

Y, por tanto, convertirlos en Parques Nacionales debía servir no sólo para atraer hacia ellos la corriente internacional del turismo, provechosa para los pueblos en el orden económico, sino también para fomentar ese movimiento de inclinación al campo, tan conveniente para la vigorización de la raza, por la mejora de las costumbres y la práctica del estudio ${ }^{73}$.

La creación de los primeros espacios naturales protegidos en España en el período comprendido entre 1916 y 1920 puede considerarse, en tal sentido, la culminación política y legal de un proceso de nacionalización simbólica de la naturaleza y del paisaje iniciado varias décadas antes, al mismo tiempo que participó en los procesos de construcción nacional de signo regeneracionista $\mathrm{y}$, dentro de ellos, en las políticas de memoria vinculadas a ciertos sectores del nacionalismo español. La protección de estos espacios intentó ofrecer símbolos nacionales unificadores y suscitó, ciertamente, el consenso de la mayoría de los parlamentarios, pero también propició y reflejó a las claras (además de ciertos conflictos intelectuales y sociales ajenos al objetivo de este trabajo) diversos tipos de disputas de carácter identitario: disputas, en primer lugar, entre las diferentes tradiciones y modalidades del nacionalismo español existentes en la época (simplificando mucho, la liberal-democrática y la católica conservadora), que aunque reconocían la importancia simbólica de Covadonga defendían lecturas e interpretaciones dispares sobre el significado nacional de la batalla y sobre la manera en que debía conmemorarse; en segundo lugar, disputas y reivindicaciones de carácter regionalista (en todo caso dentro del nacionalismo español), como las planteadas por ciertos sectores aragoneses en favor de la protección del Monte de San Juan de la Peña; disputas, en fin, entre los diversos nacionalismos españoles y el emergente nacionalismo catalán sobre el uso y el significado del adjetivo nacional para tales Parques. Las controversias ideológicas suscitadas en torno a tales espacios reflejan, pues, la pluralidad de concepciones nacionales existentes en la España de la época, así como las dificultades por consensuar unos símbolos nacionales compartidos, patente en otras muchas facetas de las políticas de la memoria de la época.

Aunque dicho género de criterios y de disputas simbólicas no desaparecía del todo en los años siguientes, a partir de mediados del decenio de 1920 y a lo largo de la II República la política de conservación de la naturaleza en Es-

72 Real Decreto de 16 de agosto de 1918, por el que se crea el Parque Nacional del Valle de Ordesa y se fijan los límites del de la Montaña Covadonga (Gaceta de Madrid de 18 de agosto: 493).

73 Real Decreto de 16 de agosto de 1918... (Gaceta de Madrid de 18 de agosto: 493). 
paña adoptaría nuevo rumbos y criterios de selección, marcados por el creciente protagonismo del naturalista Eduardo Hernández-Pacheco en la Junta Central de Parques Nacionales y el declive de la influencia en ella de Pidal, culminado con el cese de éste al frente de dicha Comisaría, en marzo de $1935^{74}$. Por razones que no viene al caso enumerar aquí (y que arrancan, en buena medida, de los conflictos suscitados entre la Administración central y las comunidades locales ante las restricciones ligadas a la implantación de los primeros Parques Nacionales), la estrategia conservacionista impulsada por Hernández-Pacheco optó por el desarrollo de nuevas figuras de protección los Sitios y Monumentos Naturales de Interés Nacional, introducidos a partir de la Real Orden del Ministerio de Fomento de 15 de julio de 1927- mucho más modestas en superficie que los Parques Nacionales, pero también mucho más diversas desde el punto de vista geográfico y mucho menos restrictivas y conflictivas desde el legal y social.

Ese giro cientifista y democratizante, que encontrará obviamente el respaldo político de la II República, propiciará la creación, entre 1929 y 1936, de quince nuevos espacios naturales protegidos (nueve de ellos antes de la caída de la monarquía), «repartidos desde Galicia a Andalucía y localizados en muy diversas condiciones naturales, de las costas a las cumbres, pasando por bosques de media montaña, roquedos calizos o lagunas de interior $\rangle^{75}$. Se superaba así el restrictivo canon estético (alpino, norteamericano, aristocrático, conservador, historicista y romántico) que había marcado la selección de los primeros parques y sitios nacionales creados en España. El mapa de los nuevos espacios naturales protegidos incorporó, ciertamente, ámbitos que, junto a otros valores, atesoraban una carga simbólica e identitaria notable, como el Guadarrama, el Montseny o el Picacho de la Virgen de la Sierra, en Cabra, pero también muchos otros seleccionados fundamentalmente con criterios científicos, en función de su interés, singularidad y representatividad en términos geológicos, geomorfológicos, hidrográficos o biogeográficos ${ }^{76}$.

Como algún autor ha subrayado, los presupuestos ideológicos que inspiran esa nueva política otorgan a la protección de la naturaleza y el paisaje un componente «más constructivamente cívico que exaltadamente patriótico», enlazándola con «la educación, la ciencia y la cultura, y no con devociones religiosas o glorias militares $\gg{ }^{77}$. Pero esa importante diferencia respecto de la etapa que había protagonizado Pidal no implicó en modo alguno que la políti-

74 Sobre las razones que condujeron a dicho cese y las relaciones entre Pidal y Hernández-Pacheco, véase FERNÁNDEZ, 2004: 285-309.

75 CASADO, 2010, 258.

76 Un mapa sintético con la localización de tales sitios y monumentos naturales declarados hasta 1936 puede verse en CASADO, 2000. Sobre los criterios de selección de estos Sitios, véanse también MATA, 2000; y MULERO, 2002.

77 CASADO, 2010: 262. 
ca conservacionista dejara de funcionar como uno de los medios esenciales de la nacionalización simbólica del paisaje, ni tampoco que renunciara a los potenciales nacionalizadores atribuidos al contacto de los ciudadanos con los espacios naturales protegidos. Más aún, al ampliar considerablemente la tipología y el número de parajes dignos de protección extendiéndolos a lo largo y ancho del territorio estatal, y al incrementar también significativamente los medios destinados a su acceso y a la divulgación de sus valores, la política conservacionista impulsada bajo la dirección de Hernández-Pacheco reforzó de hecho su capacidad de integrar y contribuir a la socialización nacional de los españoles. En palabras de Casado, esos sitios y monumentos naturales creados a partir de 1929:

resultaron no sólo paisajísticamente más variados, en representación de la rica diversidad física de la Península, sino también más abiertos a una pluralidad de lecturas identitarias y culturales. Gestas militares y hechos milagrosos daban paso a las glorias cívicas de las artes y las ciencias. A los paisajes heroicos asociados a monarcas y caudillos había que añadir otros quizá más modestos pero hondamente unidos a lo más genuino del pueblo y del genio hispanos (...) Llegada la Segunda República, los sitios y monumentos naturales podrían así proliferar a lo largo del territorio nacional para servir a todos los ciudadanos no sólo como escuela de amor a la naturaleza, sino también como patriótico símbolo de las nuevas esperanzas cívicas y democráticas depositadas en el 'alma hispana' ${ }^{78}$.

\section{BIBLIOGRAFÍA}

Altamira, Rafael, «El paisaje y los Parques Nacionales de España», Boletín de la Institución Libre de Enseñanza, XLV/436 (Madrid, 1921): 220-222.

Arco, Ricardo del, La Covadonga de Aragón: el Real Monasterio de San Juan de la Peña, Jaca, El Heraldo de Aragón, 1919.

Astié, Jean, La protection des paysages (loi des 2l-24 Avril 1906), Lyon, Impr. Paul Legendre, 1912.

Besga, Armando, Orígenes hispano-godos del Reino de Asturias, Oviedo, Real Instituto de Estudios Asturianos, 2000.

Boyd, Carolyn, «Covadonga y el regionalismo asturiano», Ayer, 64 (Madrid, 2006): 149-178.

78 CASADO, 2010: 264-265. La expresión "alma hispana" se recoge precisamente en la Orden de 31 de octubre de 1933, por la que se declaran las Lagunas de Ruidera como Sitio Natural de Interés Nacional, cuando, al describir los principales lugares comprendidos en el mismo, se menciona que "todos estos parajes constituyen la comarca elegida por nuestro inmortal Cervantes para teatro de las aventuras de Don Quijote y Sancho; personajes simbólicos del alma hispana, siempre buena, noble y generosa" (Gaceta de Madrid de 5 de noviembre: 884). 
Boyd, Carolyn, «Paisajes míticos y la construcción de las identidades regionales y nacionales: el caso del santuario de Covadonga», en Carolyn Boyd (ed.), Religión y política en la España Contemporánea, Madrid, Centro de Estudios Políticos y Constitucionales, 2007; 271-294.

Canella, Fermín, De Covadonga (Contribución al XII Centenario), Madrid, Estudio Tipográfico Jaime Ratés, 1918.

Casado, Santos, Los primeros pasos de la ecología en España, Madrid, Ministerio de Agricultura, Pesca y Alimentación y Publicaciones de la Residencia de Estudiantes, $2^{\mathrm{a}}$ edición, 2000.

Casado, Santos, Naturaleza Patria. Ciencia y sentimiento de la naturaleza en la España del regeneracionismo, Madrid, Fundación Jorge Juan / Marcial Pons, 2010.

Castañón, Juan Carlos y Frochoso, Manuel, «La naturaleza del paisaje en el Parque Nacional de los Picos de Europa», en: Eduardo Martínez de Pisón y Nicolás Ortega (eds.), La conservación del paisaje en los Parques Nacionales, Madrid, Universidad Autónoma de Madrid y Fundación Duques de Soria, 2007; 177-212.

Clarín [Leopoldo Alas], Palique, Madrid, Librería de Victoriano Suárez, 1893.

Daniels, Stephen, Fields of vision: Landscape Imaginary and National Identity in England and the United States, Princeton, Princeton University Press, 1993.

Fernández, Joaquín: «Introducción. Los parques nacionales y el turismo», en Julián Delgado et Al., Guías de los Sitios Naturales de Interés Nacional. Número 2. El Parque Nacional de la Montaña de Covadonga [1932], Madrid, Organismo Autónomo de Parques Nacionales, 2000; V-XXV.

Fernández, Joaquín, En el reino de los rebecos. Pedro Pidal, Marqués de Villaviciosa, Oviedo, Nobel, 2004.

Fernández, Joaquín y Pradas, Rosa, Los Parques Nacionales Españoles (Una aproximación histórica), Madrid, Organismo Autónomo de Parques Nacionales, 1996.

Fernández, Joaquín, y Pradas, Rosa, Historia de los Parques Nacionales españoles, Madrid, Organismo Autónomo de Parques Nacionales, 2000.

Fox, Inman, La invención de España. Madrid, Cátedra, 1997.

García Álvarez, Jacobo, «Lugares, paisajes y políticas de memoria: una lectura geográfica», Boletín de la Asociación de Geógrafos Españoles, 51 (Madrid, 2009): 175-202.

García Álvarez, Jacobo, «Paisajes nacionales, turismo y políticas de memoria: Toledo (1900-1950) », Ería, 73-74 (Oviedo, 2007): 193-212.

Gómez, Josefina, Ciencia y política de los montes españoles (1848-1936), Madrid, ICONA, 1992.

González, Juan José y Serrano, Enrique, Cultura y naturaleza en la Montaña Cantábrica, Santander, Universidad de Cantabria, 2007.

Lafuente, Modesto, Historia general de España desde los tiempos más remotos hasta nuestros dias, Madrid, Imprenta de Dionisio Chaulie, $2^{\mathrm{a}}$ ed, 1869, 30 vols. 
López-Cordón, María Victoria: «La mentalidad conservadora durante la Restauración», en José Luis García (ed.), La España de la Restauración. Política, economía, legislación y cultura, Madrid, Siglo XXI, 1990; 71-109.

López Suárez, Luis, «El renacimiento monumental de Covadonga: el Camarín y la Basílica (1872-1901)», en Covadonga. Iconografía de una devoción, Covadonga, Patronato Real de la Gruta y Sitio de Covadonga, Gobierno del Principado de Asturias y Arzobispado de Oviedo, 2001; 75-94.

Madoz, Pascual, Diccionario geográfico-estadístico-histórico de España y sus posesiones de Ultramar, Madrid, Impr. de P. Madoz y L. Sagasti, 2a ed., 16 tomos, 1845-1850.

Martínez de Pisón, Eduardo, Imagen del paisaje. La generación del 98 y Ortega y Gasset, Madrid, Caja Madrid, 1998.

Mata, Rafael, «Los orígenes de la conservación de la naturaleza en España», en Eduardo Martínez de Pisón (dir.), Estudios sobre el paisaje, Madrid, Universidad Autónoma de Madrid y Fundación Duques de Soria, 2000; 259-279.

Mata, Rafael, «Los orígenes de la política de espacio naturales protegidos en España: la relación de Sitios Notables de los distritos forestales (1917)», en Valentín Cabero et al. (eds.), El medio rural español. Cultura, paisaje y naturaleza, Alcobendas, Universidad de Salamanca/MAPA/Centro de Estudios Salmantinos, 1992; vol.2: 1067-1077.

Meinig, Donald (ed.), The Interpretation of Ordinary Landscapes: Geographical Essays, New York, Oxford University Press, 1979.

Mellado, Francisco de Paula, Recuerdos de un viage por España, Madrid, Tipografía de Mellado, 1849-1851.

Mollá, Manuel, «La Junta Central de Parques Nacionales y la Sierra de Guadarrama», Ería, 73-74 (Oviedo, 2007): 161-177.

Morales Molla, Antonio, «Historia, literatura, paisaje», en Eduardo Martínez de Pisón y Nicolás Ortega (eds.), La recuperación del paisaje, Madrid, Universidad Autónoma de Madrid - Fundación Duques de Soria, 2008; 65-86.

Morales Saro, Carmen, «Paisaje frente a arquitectura. La singularidad de Covadonga como meta para los viajeros del siglo XIX», en Los caminos y el arte. Actas VI Congreso Español de Historia del Arte, Santiago de Compostela, Universidad de Santiago de Compostela, 1989; vol. 1: 173-184.

Moreno, Ana, Turismo y nación: la definición de la identidad nacional a través de los símbolos turísticos (España, 1908-1929), tesis doctoral inédita defendida en la Universidad Complutense de Madrid, 2004.

Mulero, Alfonso, La protección de los espacios naturales en España, Madrid, Mundi-Prensa, 2002.

Núñez, Rafael, Hollada piel de toro. Del sentimiento de la naturaleza a la construcción nacional del paisaje, Madrid, Ministerio de Medio Ambiente, 2004.

Nogué, Joan, «Nacionalismo, territorio y paisaje en Cataluña», en Nicolás Ortega (ed.), Paisaje, memoria histórica e identidad nacional, Madrid, UAM-Fundación Duques de Soria, 2005; 146-169. 
Olwig, Kenneth, Landscape, Nature and the Body Politic. From Britain's Renaissance to America's New World, Madison, University of Wisconsin, 2002.

Ortega, Nicolás, «Las raíces culturales en la conservación de los paisajes», en Eduardo Martínez de Pisón (dir.), Estudios sobre el paisaje, Madrid, Universidad Autónoma de Madrid y Fundación Duques de Soria, 2000; 237-257.

Ortega, Nicolás, «La valoración patrimonial y simbólica del paisaje de Castilla (1875-1936) », Ería, nº. 73-74 (Oviedo, 2007): 137-159.

Ortega, Nicolás y García, Jacobo, «Paisaje y lugares de memoria: Covadonga y El Paular», en Eduardo Martínez de Pisón y Nicolás Ortega (eds.), Los valores del paisaje, Madrid, Ediciones de la Universidad Autónoma de Madrid / Fundación Duques de Soria, 2009; 45-93.

Pérez, Tomás, «El liberalismo español decimonónico y el ser de España: el sueño de una nación liberal y democrática», en Javier Moreno (ed.), Construir España. Nacionalismo español y procesos de nacionalización, Madrid, Centro de Estudios Políticos y Constitucionales, 2007; 83-104.

Pidal, Pedro, Parques Nacionales: proposición de ley y discursos pronunciados en el Senado..., Madrid, Impr. De Ramona Velasco, 1916.

Pidal, Pedro, Lo que es un Parque Nacional y el Parque Nacional de Covadonga, Madrid, Impr. de Ramona Velasco, 1917.

Pidal, Pedro, Política al alcance de todos, Madrid, Impr. de Ramona Velasco, 1919.

Pidal, Pedro, y Zabala, José, Picos de Europa. Contribución al estudio de las montañas españolas, Madrid, Club Alpino Español, 1918.

Ríos, Martín, «De la Restauración a la Reconquista: la construcción de un mito nacional (Una revisión historiográfica. Siglos XVI-XIX) », En la España Medieval, 28 (Madrid, 2005): 379-414.

Solé, Jordi y Bretón, Víctor, «El paraíso poseído. La política española de parques naturales (1880-1935) », Geo-critíca, 63 (Barcelona, 1986): 1-59.

Storey, David, Territory. The Claiming of Space, Harlow, Prentice Hall, 2001.

Taylor, Peter y Flint, Colin, Geografía Política, $2^{\mathrm{a}}$ ed., Madrid, Trama, 2002.

Varela, Javier, «La tradición y el paisaje: el Centro de Estudios Históricos», en: José Luis García (ed.), Los orígenes culturales de la II República. Madrid, Siglo XXI, 1993; 237-273.

Walter, François, Les figures paysageres de la nation. Territoire et paysage en Europe $\left(16^{e}-20^{e}\right.$ siècle), Paris, Editions de l'Ecole des Hautes Études en Sciences Sociales, 2004.

Wulf, Fernando, Las esencias patrias. Historiografia e historia antigua en la construcción de la identidad española (siglos XVI-XX), Barcelona, Crítica, 2003.

Recibido: 21-11-2010

Aceptado: 01-07-2011 